\title{
SYNOPSIS OF KNOWLEDGE ON CNIDARIA MEDUSOZOA FROM BRAZIL
}

\author{
Antonio C. Marques ${ }^{1}$ \\ André C. Morandini ${ }^{1}$ \\ Alvaro E. Migotto ${ }^{2}$ \\ Biota Neotropica v3 (n2) -http://www.biotaneotropica.org.br/v3n2/pt/abstract?inventory+BN01203022003 \\ Date Received : 07/14/2003 \\ Accepted :08/26/2003 \\ ${ }^{1}$ Departamento de Zoologia, Instituto de Biociências, Universidade de São Paulo, Caixa Postal 11461, 05422-970, São \\ Paulo, SP, Brazil. \\ ${ }^{2}$ Centro de Biologia Marinha, Universidade de São Paulo, Caixa Postal 83, 11600-970, São Sebastião, SP, Brazil. \\ e-mails: marques@ib.usp.br, acmorand@usp.br, aemigott@usp.br
}

\begin{abstract}
Synopsis of knowledge on Cnidaria Medusozoa from Brazil

A synopsis of knowledge concerning Medusozoa (Cnidaria) along the Brazilian coast is presented. We generated a data list with all records of medusozoans from Brazil, including information on the distribution of the species and the phase (polyp or medusa) recorded. Currently the number of species of Medusozoa recorded from Brazil is 377 (205 genera and 82 families), with 348 species of hydrozoans, 22 scyphozoans, 3 cubozoans and 1 staurozoan. Geographical and historical analyses were carried out based on the data list. The geographical analysis reveals that knowledge on biodiversity of the group is most inadequate for the North and part of the Northeastern coast. Although the Southeastern coast is the best known region in number of species and representative suprageneric taxa recorded, in general there is a lack of knowledge of the fauna in other than shallow waters, a pattern also observed for all other regions. Historically, the rapid increase of records on hydrozoans began in the 1940s and accelerated during the last decade. Investigations on coronates are all concentrated in the last decade but, in general, other groups show slow and gradual accumulation of species records. Guidelines and policies for the study of medusozoan biodiversity are suggested.
\end{abstract}

Key words: Hydrozoa, Scyphozoa, Cubozoa, Staurozoa, Fauna, South Atlantic, Polyp, Medusa, Brazil

\section{Resumo}

Sinopse sobre o conhecimento dos Cnidaria Medusozoa do Brasil

Uma sinopse sobre o conhecimento dos Medusozoa (Cnidaria) da costa brasileira é apresentada. Este estudo é baseado em uma lista com todos os registros de Medusozoa para o Brasil, incluindo informações sobre a distribuição das espécies e suas fases (pólipo ou medusa). O número de espécies de Medusozoa registradas para o Brasil até o momento é 377 (205 gêneros e 82 famílias), com 348 espécies de hidrozoários, 22 de cifozoários, 3 de cubozoários e 1 de estaurozoário. Análises geográfica e histórica também foram conduzidas. A análise geográfica mostra claramente a ausência de conhecimento sobre a biodiversidade da costa norte bem como de parte da costa nordeste do país. Embora a costa sudeste seja a melhor conhecida em termos de números de espécies e representantes de táxons supragenéricos registrados, há em geral ausência de conhecimento sobre ambientes diferentes das águas rasas, um padrão também observado para as outras regiões. Historicamente, o crescimento dos registros de hidrozoários iniciou-se após a década de 1940, com um aumento na última década; os estudos com coronados estão todos concentrados na última década mas, em geral, outros grupos mostram um acúmulo lento e gradual nos registros de espécies. Linhas gerais e políticas para o estudo da biodiversidade dos Medusozoa são sugeridas.

Palavras-chave:hidrozoários, cifozoários, cubozoários, estaurozoários, Fauna, Atlântico Sul, Pólipo, Medusa, Brasil

http://www.biotaneotropica.org.br 


\section{Introduction}

Despite many difficulties Brazil is one of the leading countries in science in Latin America, responsible for $1 \%$ of the science produced in the world (Macilwain, 1999). The majority of this research is in biological sciences, most of it non-applied. However, the country is far from having an adequate knowledge of its fauna and flora ( $c f$. Lewinsohn $\&$ Prado, 2002; Migotto \& Marques, in press), necessary for environmental management and conservation policies. The concern is even more critical because the country is considered to be megadiverse, with rich biotas in habitats including the Amazon and Atlantic rainforest, or Pantanal wetlands, regions with extensive areas still representing pristine and important parts of the biosphere.

The knowledge of marine environments is even less adequate than for continental ones. The coastline of the country is extensive (about $8500 \mathrm{~km}$ ) and heterogeneous, and includes a great variety of habitats and biomes. There is a wide range of surface water temperature (subtropical to warm tropical) influenced by two major equatorial oceanic currents - South Equatorial Current and Brazil Current. Environmental heterogeneity is also evident in estuaries such as the Amazon and others in the North. In addition, varied mangrove ecosystems occur along the coast. A lack of significant freshwater outflows in most of the Northeast region allows for the presence of coral reef formations. Other noteworthy influences on marine biodiversity in Brazil include the seasonal balance between Brazil Current and Southern Atlantic Central Water in the Southeastern / Southern regions and effects of the Rio de La Plata and Lagoa dos Patos outflow waters, which are driven northwards by the Falklands Current in the Southern region (Boltovskoy et al., 1999; MMA/SBF, 2002; Vilaça, 2002). The continental shelf is wide in some areas, especially off the states of Amapá and Amazonas (80 and 160 miles, respectively) to the Piauí coast, and also along southern Bahia, Espírito Santo, and most of the southeast and south Brazilian coast. By contrast it is narrow along the remaining states of Northeast region, extending offshore only 20-30 miles (MMA/SBF, 2002). Traditional biogeographical schemes divide the Brazilian coast into three faunal zones - tropical, subtropical and transitional (sensu Palacio, 1982). Therefore, the littoral might theoretically be expected to support a considerable number of species.

Notwithstanding pioneering work by Ernst and Eveline Marcus, among others, Brazilian tradition in marine systematics can be considered to be still developing, with several higher-level groups, including phyla, without a single species recorded along the entire coast ( $c f$. Migotto \& Marques, in press). This is a consequence of the historical development of taxonomy and the usual focus on a few zoological groups. Only a few isolated programs have been established thus far to solve or attenuate the problem
(Migotto et al., 2002; Migotto \& Marques, in press).

The authors of this study are experts on cnidarians, a mostly marine, diversified group that is ecologically important in all seas of the world. Cnidarians are characteristic of both pelagic and benthic habitats inasmuch as several of them have a complex life cycle including polyps (mostly benthic and sessile) and medusae (mostly planktonic and swimming). Besides their obvious ecological importance, cnidarians in general have significant impacts on human life, including commercial (e.g., for tourism, pharmaceutics, fisheries) (UNEP, 1991; Purcell et al., 2001), environmental (e.g., as habitat indicators) and medical interests (e.g., Freitas et al., 1995; Morandini \& Marques, 1997; Marques et al., 2002; Haddad Jr. et al., 2002). Moreover, they are amongst the most basal animals, being particularly important in evolutionary studies (e.g., cf. Nielsen, 2001).

Herein we present a diagnosis of the present status of knowledge of the Cnidaria for Brazil. To accomplish this, we prepared a species data bank that included literature references and species records (Migotto et al., 2002). In this study, we traced the development of the study of the group from both historical and geographical perspectives. Information was assembled to provide a synopsis of the group from Brazil that could guide future research and management. This paper, the second part of our study, characterizes the medusozoan fauna by taxa and by state/region. It indicates geographical areas where future biodiversity investigations are especially needed, and points to those taxa in which systematic efforts should be concentrated.

\section{Faunistic and historical data}

Data on numbers of species, genera, and families of the more inclusive taxa (e.g., subclasses and orders) are summarized in Table 1. The total number of species of medusozoans so far recorded from Brazil is 377, though 39 of these ( $10.3 \%$ of the total) are presently undetermined and may actually include ones that have already been recorded. The 377 species represent 205 genera and 82 families. Worldwide, the total number of species of Medusozoa is estimated to be $c a$. 4,000. Therefore, Brazilian records represent approximately $9.4 \%$ of that total, possibly an underestimate.

The high number of undetermined species $(10.3 \%)$ is unevenly dispersed among the medusozoans, with hydrozoans accounting for $10.6 \%$ of the undetermined species (37 out of 348 species), scyphozoans $9.0 \%$ (2 out of 22) and cubozoans and staurozoans having no undetermined species. These values are due to the lower number of species of cubozoans (3) and staurozoans (1) compared with hydrozoans and scyphozoans.

Among hydrozoans, the proportion of undetermined species is higher in anthoathecates $(19.8 \%)$, leptothecates $(12.0 \%)$, and narcomedusans $(11.8 \%)$ in comparison to the 
Table 1.- Numbers of Brazilian marine medusozoans assigned to various taxa.

\# families \# genera \# genera indet total genera \# species \# species indet total species

\begin{tabular}{|c|c|c|c|c|c|c|c|c|}
\hline Medusozoa & & 82 & 196 & 9 & 205 & 338 & 39 & 377 \\
\hline Hydrozoa & & 66 & 173 & 9 & 182 & 311 & 37 & 348 \\
\hline Anthoathecata & & 29 & 54 & 2 & 56 & 77 & 19 & 96 \\
\hline \multirow[t]{13}{*}{ Filifera } & & 12 & 28 & 1 & 29 & 43 & 11 & 54 \\
\hline & Bougainvilliidae & & 6 & 0 & 6 & 11 & 3 & 14 \\
\hline & Calycopsidae & & 2 & 0 & 2 & 2 & 1 & 3 \\
\hline & Clavidae & & 5 & 1 & 6 & 5 & 2 & 7 \\
\hline & Cytaeididae & & 1 & 0 & 1 & 1 & 0 & 1 \\
\hline & Eudendriidae & & 1 & 0 & 1 & 8 & 1 & 9 \\
\hline & Hydractiniidae & & 2 & 0 & 2 & 3 & 1 & 4 \\
\hline & Niobiidae & & 1 & 0 & 1 & 1 & 0 & 1 \\
\hline & Pandeidae & & 6 & 0 & 6 & 9 & 1 & 10 \\
\hline & Proboscidactylidae & & 1 & 0 & 1 & 1 & 1 & 2 \\
\hline & Protiaridae & & 1 & 0 & 1 & 1 & 0 & 1 \\
\hline & Rhysiidae & & 1 & 0 & 1 & 0 & 1 & 1 \\
\hline & Stylasteridae & & 1 & 0 & 1 & 1 & 0 & 1 \\
\hline \multirow[t]{13}{*}{ Capitata } & & 17 & 26 & 1 & 27 & 34 & 8 & 42 \\
\hline & Asyncorynidae & & 1 & 0 & 1 & 1 & 0 & 1 \\
\hline & Cladocorynidae & & 1 & 0 & 1 & 1 & 0 & 1 \\
\hline & Cladonematidae & & 1 & 0 & 1 & 1 & 1 & 2 \\
\hline & Cladosarsiidae & & 0 & 1 & 1 & 0 & 1 & 1 \\
\hline & Corymorphidae & & 2 & 0 & 2 & 5 & 0 & 5 \\
\hline & Corynidae & & 5 & 0 & 5 & 7 & 1 & 8 \\
\hline & Eleutheriidae & & 1 & 0 & 1 & 0 & 1 & 1 \\
\hline & Euphysidae & & 1 & 0 & 1 & 1 & 0 & 1 \\
\hline & Milleporidae & & 1 & 0 & 1 & 4 & 2 & 6 \\
\hline & Moerisiidae & & 1 & 0 & 1 & 1 & 0 & 1 \\
\hline & Pennariidae & & 1 & 0 & 1 & 1 & 0 & 1 \\
\hline & Porpitidae & & 2 & 0 & 2 & 2 & 0 & 2 \\
\hline
\end{tabular}




\begin{tabular}{|c|c|c|c|c|c|c|c|c|}
\hline & Solanderiidae & & 1 & 0 & 1 & 1 & 0 & 1 \\
\hline & Sphaerocorynidae & & 1 & 0 & 1 & 1 & 1 & 2 \\
\hline & Tubulariidae & & 5 & 0 & 5 & 6 & 0 & 6 \\
\hline & Zancleidae & & 1 & 0 & 1 & 1 & 1 & 2 \\
\hline & Zancleopsidae & & 1 & 0 & 1 & 1 & 0 & 1 \\
\hline Leptothecata & & 20 & 58 & 7 & 65 & 117 & 16 & 133 \\
\hline Conica & & 19 & 52 & 4 & 56 & 99 & 8 & 107 \\
\hline & Aequoridae & & 2 & 1 & 3 & 2 & 1 & 3 \\
\hline & Aglaopheniidae & & 5 & 0 & 5 & 15 & 0 & 15 \\
\hline & Blackfordiidae & & 1 & 0 & 1 & 1 & 0 & 1 \\
\hline & Campanulinidae & & 4 & 1 & 5 & 4 & 2 & 6 \\
\hline & Cirrholoveniidae & & 1 & 0 & 1 & 1 & 0 & 1 \\
\hline & Dipleurosomatidae & & 1 & 0 & 1 & 1 & 0 & 1 \\
\hline & Eirenidae & & 5 & 0 & 5 & 7 & 0 & 7 \\
\hline & Eucheilotidae & & 1 & 0 & 1 & 4 & 0 & 4 \\
\hline & Haleciidae & & 4 & 1 & 5 & 8 & 3 & 11 \\
\hline & Halopterididae & & 3 & 0 & 3 & 6 & 0 & 6 \\
\hline & Kirchenpaueriidae & & 2 & 0 & 2 & 2 & 0 & 2 \\
\hline & Lafoeidae & & 4 & 0 & 4 & 5 & 1 & 6 \\
\hline & Laodiceidae & & 1 & 0 & 1 & 2 & 0 & 2 \\
\hline & Lovenellidae & & 1 & 0 & 1 & 1 & 0 & 1 \\
\hline & Malagaziidae & & 3 & 1 & 4 & 3 & 1 & 4 \\
\hline & Mitrocomidae & & 2 & 0 & 2 & 2 & 0 & 2 \\
\hline & Plumulariidae & & 3 & 0 & 3 & 7 & 0 & 7 \\
\hline & Sertulariidae & & 8 & 0 & 8 & 26 & 0 & 26 \\
\hline & Syntheciidae & & 1 & 0 & 1 & 2 & 0 & 2 \\
\hline Proboscoida & & 1 & 6 & 3 & 9 & 18 & 8 & 26 \\
\hline & Campanulariidae & & 6 & 3 & 9 & 18 & 8 & 26 \\
\hline Limnomedusae & & 1 & 5 & 0 & 5 & 6 & 0 & 6 \\
\hline & Olindiidae & & 5 & 0 & 5 & 6 & 0 & 6 \\
\hline Narcomedusae & & 3 & 7 & 0 & 7 & 15 & 2 & 17 \\
\hline & Aeginidae & & 3 & 0 & 3 & 3 & 0 & 3 \\
\hline & Cuninidae & & 2 & 0 & 2 & 5 & 0 & 5 \\
\hline & Solmarisidae & & 2 & 0 & 2 & 7 & 2 & 9 \\
\hline Siphonophorae & & 10 & 36 & 0 & 36 & 83 & 0 & 83 \\
\hline
\end{tabular}




\begin{tabular}{|c|c|c|c|c|c|c|c|}
\hline Calycophorae & 5 & 25 & 0 & 25 & 69 & 0 & 69 \\
\hline Abylidae & & 5 & 0 & 5 & 10 & 0 & 10 \\
\hline Clausophyidae & & 4 & 0 & 4 & 9 & 0 & 9 \\
\hline Diphyidae & & 8 & 0 & 8 & 35 & 0 & 35 \\
\hline Hippopodiidae & & 2 & 0 & 2 & 5 & 0 & 5 \\
\hline Prayidae & & 6 & 0 & 6 & 10 & 0 & 10 \\
\hline Cystonectae & 1 & 1 & 0 & 1 & 1 & 0 & 1 \\
\hline Physaliidae & & 1 & 0 & 1 & 1 & 0 & 1 \\
\hline Physonectae & 4 & 10 & 0 & 10 & 13 & 0 & 13 \\
\hline Agalmatidae & & 6 & 0 & 6 & 9 & 0 & 9 \\
\hline Athorybiidae & & 2 & 0 & 2 & 2 & 0 & 2 \\
\hline Forskaliidae & & 1 & 0 & 1 & 1 & 0 & 1 \\
\hline Physophoridae & & 1 & 0 & 1 & 1 & 0 & 1 \\
\hline Trachymedusae & 3 & 13 & 0 & 13 & 13 & 0 & 13 \\
\hline Geryoniidae & & 2 & 0 & 2 & 2 & 0 & 2 \\
\hline Halicreatidae & & 1 & 0 & 1 & 1 & 0 & 1 \\
\hline Rhopalonematidae & & 10 & 0 & 10 & 10 & 0 & 10 \\
\hline Scyphozoa & 14 & 16 & 0 & 16 & 20 & 2 & 22 \\
\hline Coronatae & 4 & 5 & 0 & 5 & 8 & 1 & 9 \\
\hline Atollidae & & 1 & 0 & 1 & 2 & 0 & 2 \\
\hline Linuchidae & & 1 & 0 & 1 & 1 & 0 & 1 \\
\hline Nausithoidae & & 2 & 0 & 2 & 4 & 1 & 5 \\
\hline Periphyllidae & & 1 & 0 & 1 & 1 & 0 & 1 \\
\hline Rhizostomeae & 5 & 5 & 0 & 5 & 5 & 0 & 5 \\
\hline Cassiopeidae & & 1 & 0 & 1 & 1 & 0 & 1 \\
\hline Catostylidae & & 1 & 0 & 1 & 1 & 0 & 1 \\
\hline Lychnorhizidae & & 1 & 0 & 1 & 1 & 0 & 1 \\
\hline Mastigiidae & & 1 & 0 & 1 & 1 & 0 & 1 \\
\hline Stomolophidae & & 1 & 0 & 1 & 1 & 0 & 1 \\
\hline Semaeostomeae & 3 & 4 & 0 & 4 & 5 & 1 & 6 \\
\hline Cyaneidae & & 1 & 0 & 1 & 1 & 0 & 1 \\
\hline Pelagiidae & & 2 & 0 & 2 & 3 & 0 & 3 \\
\hline Ulmaridae & & 1 & 0 & 1 & 1 & 1 & 2 \\
\hline Incertae Sedis & 2 & 2 & 0 & 2 & 2 & 0 & 2 \\
\hline
\end{tabular}


Marques, A. C. (et al.) - Biota Neotropica, v3 (n2) - BN01203022003

Teissieridae

Incertae Sedis

\begin{tabular}{|c|c|c|c|c|c|c|}
\hline & 1 & 0 & 1 & 1 & 0 & 1 \\
\hline & 1 & 0 & 1 & 1 & 0 & 1 \\
\hline \multirow[t]{3}{*}{2} & 3 & 0 & 3 & 3 & 0 & 3 \\
\hline & 2 & 0 & 2 & 2 & 0 & 2 \\
\hline & 1 & 0 & 1 & 1 & 0 & 1 \\
\hline 1 & 1 & 0 & 1 & 1 & 0 & 1 \\
\hline \multirow[t]{2}{*}{1} & 1 & 0 & 1 & 1 & 0 & 1 \\
\hline & 1 & 0 & 1 & 1 & 0 & 1 \\
\hline
\end{tabular}

Stauromedusae

Kishinouyeidae 
Table 2.- Numbers of Brazilian marine medusozoans according to geographic area. Codes used for the states, from south to north of the country, are: RS (Rio Grande do Sul); SC (Santa Catarina); PR (Paraná); SP (São Paulo); RJ (Rio de Janeiro); ES (Espírito Santo); BA (Bahia); SE (Sergipe); AL (Alagoas); PE (Pernambuco) PB (Paraíba); RN (Rio Grande do Norte); CE (Ceará); PI (Piauí); MA (Maranhão); PA (Pará); AP (Amapá). Oceanic islands were also individually considered and abbreviated as AR (Atol da Rocas); FN (Fernando de Noronha) and TRI (Trindade Island). The regions adopted in the study are as defined geopolitically; these are abbreviated as S(South, includes the states RS, SC, PR); SE (Southeast, includes SP, RJ, ES); NE (Northeast, includes BA, SE, AL, PE, PB, RN, CE, PI, MA, plus the islands $A R$ and $F N)$ and $N$ (North, includes $P A, A M, A P)$.

\begin{tabular}{|c|c|c|c|c|c|c|c|c|c|c|c|c|c|c|c|c|c|c|c|c|c|c|c|c|c|}
\hline & & $\mathrm{RS}$ & SC & PR & SP & RJ & ES & BA & SE & $A L$ & PE & PB & $\mathrm{RN}$ & CE & $\mathrm{PI}$ & MA & PA & AP & AR & FN & TRI & $S$ & SE & $\mathrm{NE}$ & $\mathrm{N}$ \\
\hline Medusozoa & & 127 & 100 & 100 & 231 & 163 & 151 & 126 & 92 & 95 & 136 & 86 & 86 & 85 & 84 & 85 & 93 & 84 & 2 & 33 & 2 & 168 & 292 & 208 & 97 \\
\hline Hydrozoa & & 116 & 87 & 89 & 212 & 148 & 139 & 113 & 82 & 85 & 126 & 76 & 76 & 74 & 74 & 75 & 82 & 74 & 2 & 33 & 2 & 154 & 270 & 194 & 86 \\
\hline & Anthoathecata & 16 & 8 & 8 & 52 & 24 & 20 & 15 & 2 & 5 & 15 & 2 & 2 & 1 & 1 & 1 & 1 & 0 & 2 & 5 & 1 & 30 & 78 & 36 & 1 \\
\hline & Leptothecata & 16 & 6 & 12 & 79 & 51 & 48 & 24 & 1 & 4 & 33 & 0 & 0 & 0 & 0 & 0 & 2 & 0 & 0 & 9 & 0 & 27 & 102 & 56 & 2 \\
\hline & Limnomedusae & 2 & 2 & 0 & 2 & 0 & 0 & 0 & 0 & 0 & 0 & 0 & 0 & 0 & 0 & 0 & 0 & 0 & 0 & 0 & 0 & 5 & 2 & 2 & 0 \\
\hline & Narcomedusae & 6 & 1 & 0 & 6 & 1 & 0 & 0 & 5 & 2 & 3 & 0 & 0 & 0 & 0 & 0 & 0 & 0 & 0 & 0 & 0 & 13 & 12 & 15 & 5 \\
\hline & Siphonophorae & 69 & 69 & 69 & 69 & 69 & 70 & 72 & 72 & 73 & 74 & 74 & 74 & 73 & 73 & 74 & 78 & 74 & 0 & 18 & 1 & 69 & 70 & 76 & 77 \\
\hline & Trachymedusae & 7 & 1 & 0 & 4 & 3 & 1 & 2 & 2 & 1 & 1 & 0 & 0 & 0 & 0 & 0 & 1 & 0 & 0 & 1 & 0 & 10 & 6 & 9 & 1 \\
\hline Scyphozoa & & 10 & 11 & 9 & 17 & 13 & 9 & 11 & 8 & 8 & 8 & 8 & 8 & 9 & 8 & 8 & 8 & 8 & 0 & 0 & 0 & 12 & 19 & 12 & 8 \\
\hline & Coronatae & 5 & 4 & 4 & 7 & 5 & 4 & 5 & 4 & 4 & 4 & 4 & 4 & 5 & 4 & 4 & 4 & 4 & 0 & 0 & 0 & 5 & 7 & 6 & 4 \\
\hline & Rhizostomeae & 2 & 3 & 2 & 4 & 2 & 2 & 3 & 2 & 2 & 2 & 2 & 2 & 2 & 2 & 2 & 2 & 2 & 0 & 0 & 0 & 3 & 4 & 3 & 2 \\
\hline & Semaeostomeae & 3 & 4 & 3 & 6 & 4 & 3 & 3 & 2 & 2 & 2 & 2 & 2 & 2 & 2 & 2 & 2 & 2 & 0 & 0 & 0 & 4 & 6 & 3 & 2 \\
\hline & Incertae sedis & 0 & 0 & 0 & 0 & 2 & 0 & 0 & 0 & 0 & 0 & 0 & 0 & 0 & 0 & 0 & 0 & 0 & 0 & 0 & 0 & 0 & 2 & 0 & 0 \\
\hline Staurozoa & & 0 & 0 & 0 & 0 & 0 & 1 & 0 & 0 & 0 & 0 & 0 & 0 & 0 & 0 & 0 & 0 & 0 & 0 & 0 & 0 & 0 & 1 & 0 & 0 \\
\hline Cubozoa & & 1 & 2 & 2 & 2 & 2 & 2 & 2 & 2 & 2 & 2 & 2 & 2 & 2 & 2 & 2 & 3 & 2 & 0 & 0 & 0 & 2 & 2 & 2 & 3 \\
\hline
\end{tabular}


Table 3.- Numbers of new records of medusozoan species from Brazilian waters, 1821-2002.

\begin{tabular}{|c|c|c|c|c|c|c|c|c|c|c|c|c|c|c|c|c|c|c|c|c|}
\hline & & $\begin{array}{l}1821- \\
1830 \\
\end{array}$ & $\begin{array}{l}1831- \\
1840 \\
\end{array}$ & $\begin{array}{l}1841- \\
1850 \\
\end{array}$ & $\begin{array}{l}1851- \\
1860 \\
\end{array}$ & $\begin{array}{l}1861- \\
1870 \\
\end{array}$ & $\begin{array}{l}1871- \\
1880 \\
\end{array}$ & $\begin{array}{c}1881- \\
1890 \\
\end{array}$ & $\begin{array}{l}1891- \\
1900 \\
\end{array}$ & $\begin{array}{c}1901- \\
1910 \\
\end{array}$ & $\begin{array}{c}1911- \\
1920 \\
\end{array}$ & $\begin{array}{l}1921- \\
1930 \\
\end{array}$ & $\begin{array}{l}1931- \\
1940 \\
\end{array}$ & $\begin{array}{c}1941- \\
1950 \\
\end{array}$ & $\begin{array}{c}1951- \\
1960 \\
\end{array}$ & $\begin{array}{l}1961- \\
1970 \\
\end{array}$ & $\begin{array}{c}1971- \\
1980 \\
\end{array}$ & $\begin{array}{c}1981- \\
1990 \\
\end{array}$ & $\begin{array}{l}1991- \\
2000 \\
\end{array}$ & $\begin{array}{l}2001- \\
2002 \\
\end{array}$ \\
\hline Medusozoa & & 2 & 0 & 1 & 3 & 4 & 1 & 12 & 4 & 12 & 4 & 2 & 5 & 30 & 48 & 14 & 75 & 38 & 98 & 19 \\
\hline Hydrozoa & & 0 & 0 & 1 & 1 & 4 & 0 & 10 & 4 & 11 & 4 & 1 & 4 & 29 & 46 & 13 & 74 & 38 & 89 & 17 \\
\hline & Anthoathecata & 0 & 0 & 1 & 0 & 1 & 0 & 0 & 0 & 0 & 1 & 0 & 1 & 1 & 17 & 7 & 10 & 15 & 33 & 9 \\
\hline & Leptothecata & 0 & 0 & 0 & 0 & 0 & 0 & 10 & 4 & 11 & 2 & 1 & 1 & 27 & 15 & 5 & 10 & 8 & 30 & 8 \\
\hline & Limnomedusae & 0 & 0 & 0 & 0 & 2 & 0 & 0 & 0 & 0 & 0 & 0 & 0 & 1 & 0 & 0 & 2 & 1 & 0 & 0 \\
\hline & Narcomedusae & 0 & 0 & 0 & 0 & 1 & 0 & 0 & 0 & 0 & 1 & 0 & 1 & 0 & 8 & 0 & 3 & 2 & 0 & 0 \\
\hline & Siphonophorae & 0 & 0 & 0 & 0 & 0 & 0 & 0 & 0 & 0 & 0 & 0 & 0 & 0 & 0 & 0 & 49 & 8 & 26 & 0 \\
\hline & Trachymedusae & 0 & 0 & 0 & 1 & 0 & 0 & 0 & 0 & 0 & 0 & 0 & 1 & 0 & 6 & 1 & 0 & 4 & 0 & 0 \\
\hline Scyphozoa & & 2 & 0 & 0 & 0 & 0 & 1 & 2 & 0 & 1 & 0 & 1 & 1 & 1 & 2 & 1 & 1 & 0 & 7 & 2 \\
\hline & Coronatae & 0 & 0 & 0 & 0 & 0 & 0 & 0 & 0 & 1 & 0 & 0 & 0 & 0 & 1 & 0 & 0 & 0 & 6 & 1 \\
\hline & Rhizostomeae & 1 & 0 & 0 & 0 & 0 & 1 & 0 & 0 & 0 & 0 & 0 & 0 & 1 & 0 & 1 & 0 & 0 & 1 & 0 \\
\hline & Semaeostomeae & 1 & 0 & 0 & 0 & 0 & 0 & 2 & 0 & 0 & 0 & 1 & 0 & 0 & 1 & 0 & 0 & 0 & 0 & 1 \\
\hline & Incertae sedis & 0 & 0 & 0 & 0 & 0 & 0 & 0 & 0 & 0 & 0 & 0 & 1 & 0 & 0 & 0 & 1 & 0 & 0 & 0 \\
\hline Staurozoa & & 0 & 0 & 0 & 0 & 0 & 0 & 0 & 0 & 0 & 0 & 0 & 0 & 0 & 0 & 0 & 0 & 0 & 1 & 0 \\
\hline Cubozoa & & 0 & 0 & 0 & 2 & 0 & 0 & 0 & 0 & 0 & 0 & 0 & 0 & 0 & 0 & 0 & 0 & 0 & 1 & 0 \\
\hline
\end{tabular}




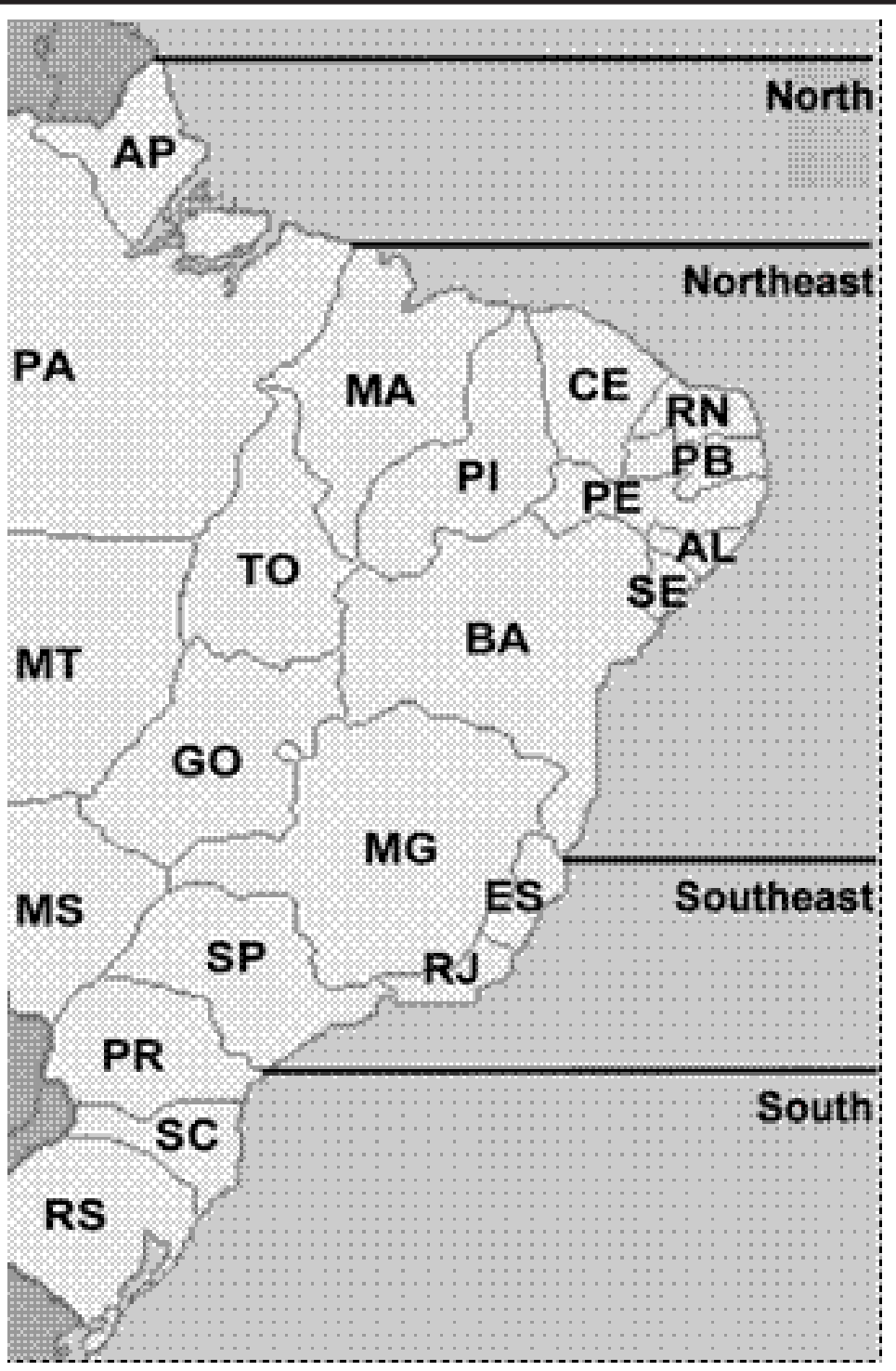

Figure 1.- Political map of Brazilian coast, indicating the regions and the states. 


\section{Hydrozoa}

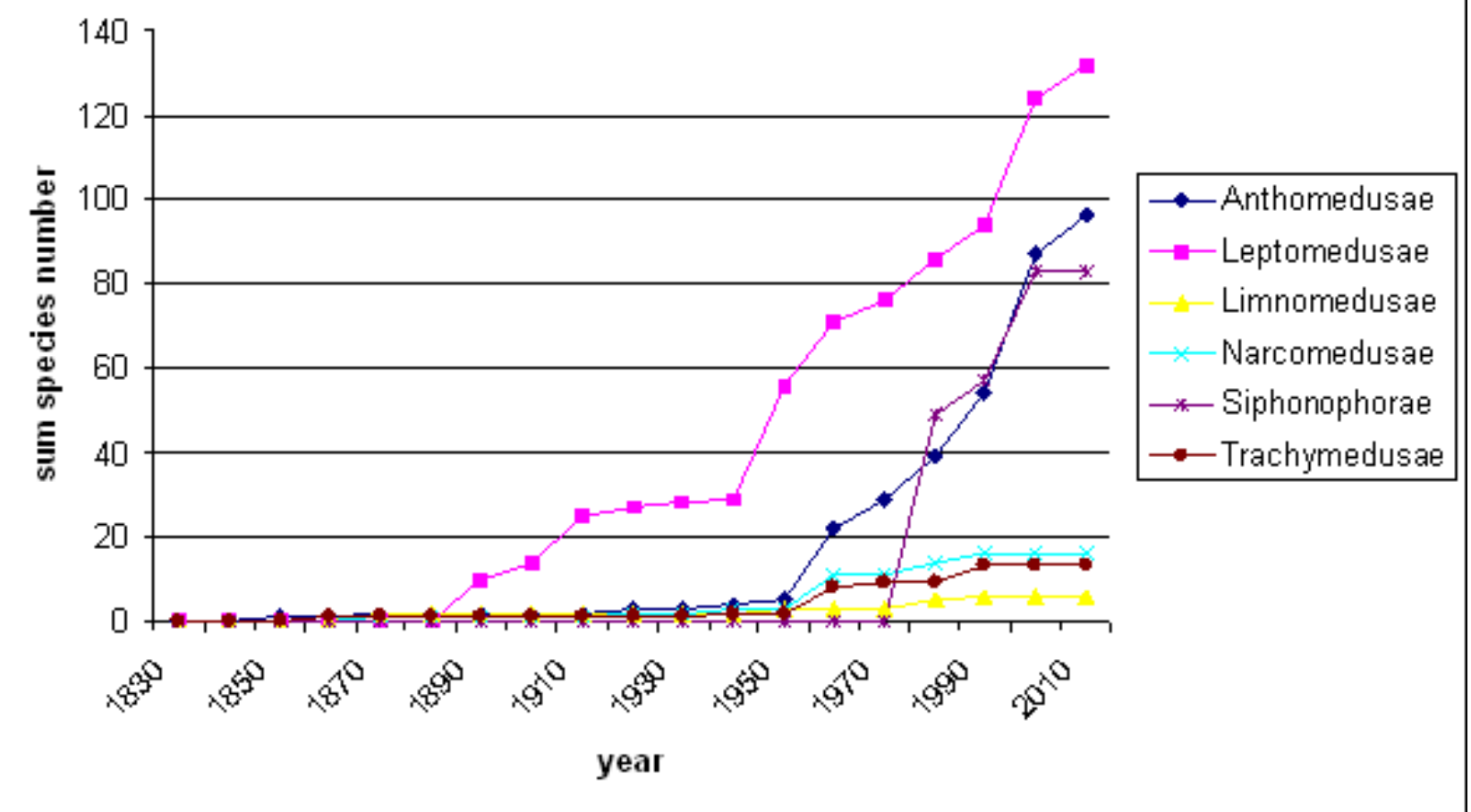

Figure 2.- Sum of accumulated new records for species for Hydrozoa.

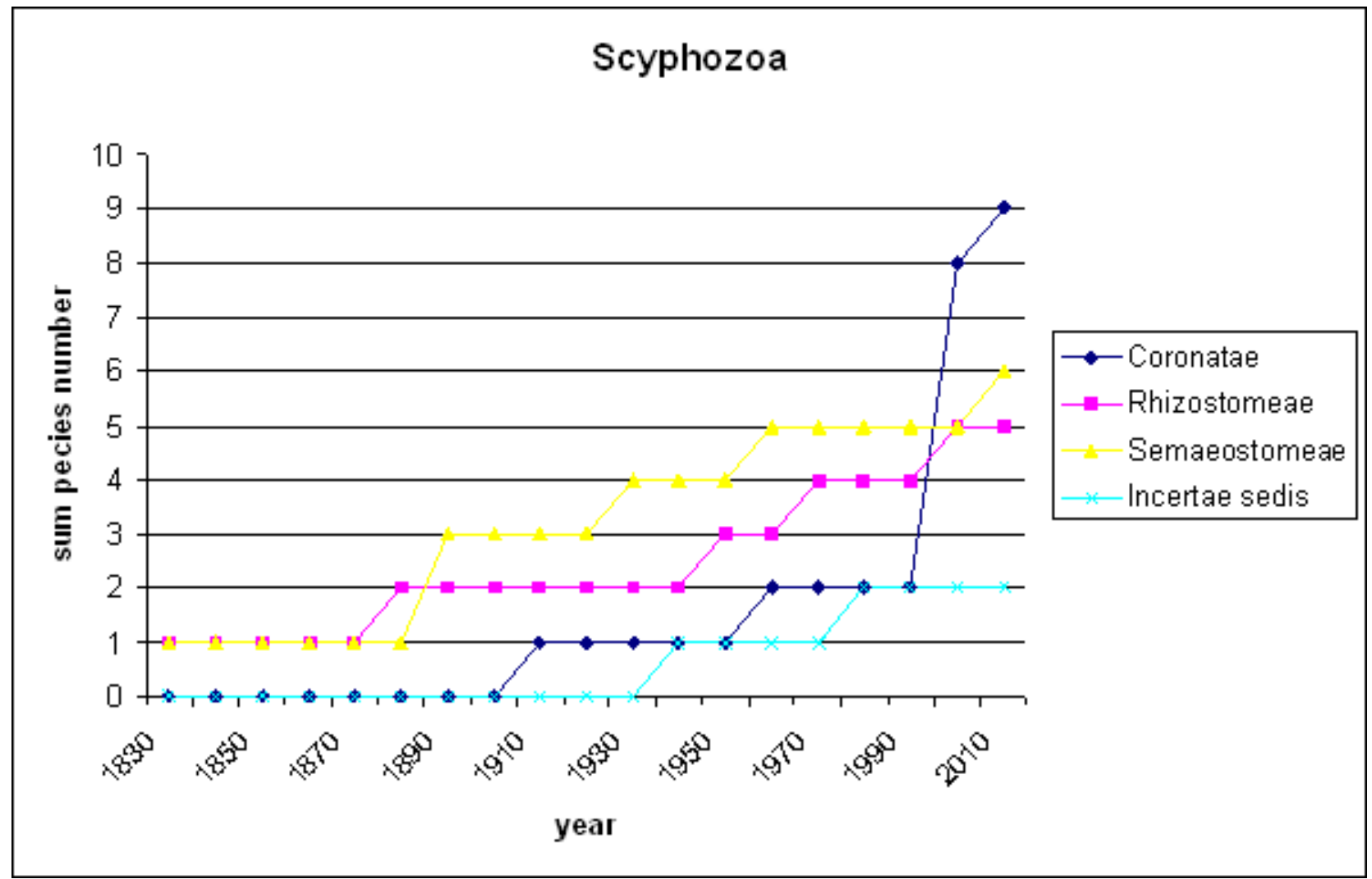

Figure 3.- Sum of accumulated new records for species for Scyphozoa. 
others $(0 \%$ for limnomedusans, siphonophores, and trachymedusans). This can be attributed to the low number of species of limnomedusans and trachymedusans. For siphonophores, the absence of undetermined species is possibly due to the few monographs dealing with the South Atlantic fauna. In some cases, the authors of these monographs were highly decisive with respect to species identification (Alvariño, 1971, 1981), indicating no doubts concerning species records even if the material was possibly not collected and not deposited in museums (Pugh, 1999). As for certain other groups, the higher number of undetermined species is attributed to different reasons. Species of narcomedusans (Solmaris spp. by Moreira, 1973; and Pegantha sp. by Goy, 1979) reflect occasional difficulties found in the taxonomy of specific genera. As for anthoathecates and leptothecates, their often complex and incompletely known life cycles sometimes hinder species identification. A metagenesis between polyp and medusa stages is typical in representatives of these two taxa, although there is often some degree of reduction in one of the phases. The identification of these leptolids is therefore dependent, to a considerable extent, on knowledge of the life cycles of the species.

Assessments of total species numbers of medusozoans in a given geographic area are rare, and none is recent. Hence, comparisons of the total number of medusozoans with other regions are difficult, and only comparisons within groups can be taken as parameters.

The richest group in number of species of medusozoans (and cnidarians) in Brazil is Hydrozoa (348 species, 173 genera, 66 families), corresponding to $10.7 \%$ of the known species of the world (3260 species in the estimation by Schuchert, 1998, for species described up to 1997). In turn, most hydrozoans are included in the Leptothecata (133 species, 58 genera, and 20 families), Anthoathecata (96 species, 54 genera, and 29 families), and Siphonophorae (83 species, 36 genera, and 10 families).

The knowledge on siphonophores, as already remarked, is based on a small number of papers. The last report on the group relevant to Brazilian waters was published by Pugh (1999). Species distributions in his publication were inferred from water masses present here and not on primary sources or on zoological collections. Considering the total estimated number of species per group, siphonophores would appear to be the best known in Brazilian waters ( $c a .46 \%$ of the total number of species, $c a .180$ for the world after Schuchert, 1998). As noted by Schuchert (1998: 214), the siphonophore curve of accumulation of species per time shows no sign of convergence in the near future, meaning a continuous increase in their species richness. For the Brazilian coast, studies will certainly increase knowledge and verify that certain species occur there.

Considering other hydrozoan groups, the high per- centage of species recorded for each group in comparison to the total number of species described (after Schuchert, 1998 ) is also noticeable for Narcomedusae ( $c a .40 \%$ of the ca. 43 total species) and Trachymedusae (ca. 23.6\% of the ca. 55 total species). Coincidentally, the best-known groups (siphonophores, narcomedusans, and trachymedusans) are mostly planktonic. However, knowledge on Narcomedusae and Trachymedusae worldwide can be considered stable, the curve of accumulation of species per time approaching the convergence, although not much taxonomic work or descriptions of species have been carried out during recent decades (only ca. 20\% of the species of the group were described since 1900; see Schuchert, 1998); a situation apparently not different in Brazil (also for Limnomedusae; see figure 1).

Knowledge of Brazilian Anthoathecata and Leptothecata (traditionally called "hydroids") is based on numerous publications, only two of which are monographs (Migotto, 1993; Marques, 2001). Totaling 229 species (112 genera, 49 families), these two groups are actually the poorest known in Brazil in comparison with the other Hydrozoa. They represent about 9.4\% (Anthoathecata) and 7\% (Leptothecata) of the total species worldwide, $c a .1020$ and 1900 species respectively (see Schuchert, 1998). For Brazil, these groups seem to be far from the convergence of their curves of accumulation of species (figure 2). The literature data indicate that both the less diverse and planktonic groups of hydrozoans, in which description of new species was slower during the 20th century, are the best known, whereas the highly rich species groups including both benthic and planktonic phases (Anthoathecata and Leptothecata) are not satisfactorily known.

The other medusozoans - Staurozoa (Marques \& Collins, 2004), Scyphozoa, and Cubozoa - are small groups in number of species. Scyphozoans and cubozoans are relatively well known by the layman because they include some large and poisonous species. Cubozoa includes $c a$. 16 species (Bouillon, 1994), mostly restricted to warmer waters of the globe. For Brazil, Migotto et al. (2002) presented records of three species of Cubozoa ( $\mathrm{ca} .19 \%$ of the total). A single species of Staurozoa has been recorded in Brazilian waters, possibly an underestimated number.

The total number of the species of Scyphozoa is about 200 (Mianzan \& Cornelius, 1999), 22 of which have been recorded to date from Brazil (11\% of the total). After the paper by Vannucci (1957a), no well-established research teams focused on the group and few publications dealing with scyphozoans appeared until the 1970s. By the mid1990 s, however, a subsequent increase of almost $1 / 3$ occurred in the number of known scyphozoans, due exclusively to new records of species of Coronatae (especially the polyp stages). This indicates that the lack of species records may be due to inadequate study rather than actual 
faunal impoverishment. For the Scyphozoa in particular, we believe that numbers of species are likely to rise.

The families with the largest numbers of species are the Diphyidae (10\% of the total number of species), Sertulariidae and Campanulariidae (7.5\%), Aglaopheniidae (4.3\%), and Bougainvilliidae (4.0\%). Therefore five families (7.5\% of the total) account for $33 \%$ of the diversity of Hydrozoa. Among the Scyphozoa the families with the largest numbers of species are Nausithoidae $(22.7 \%$ of the total number of species of scyphozoans) and Pelagiidae (13.6\%). Similarly, two families (14.3\% of the total) account for $35 \%$ of the species of Scyphozoa.

Quantitative comparisons of the medusozoan fauna of Brazil with that of other geographical regions provides clues about the extent of our current faunal knowledge. Patterns of diversity among mostly planktonic hydrozoan groups (Trachymedusae, Narcomedusae and Siphonophorae), seem consistent with those reported elsewhere. For instance, reported diversity in waters of the Benguela Current (southeastern Atlantic, off the coast of southern Africa) included 52 species of siphonophores (Pagès \& Gili, 1992), 10 of Narcomedusae (Pagès et al., 1992) and four of Trachymedusae (Pagès et al., 1992). All of these numbers are lower than existing records from Brazil. In British waters, 56 species of siphonophores are known (Kirkpatrick \& Pugh, 1984). By contrast, 20 species of Narcomedusae and 18 species of Trachymedusae have been reported from the Mediterranean Sea (Boero \& Bouillon, 1993). Such numbers exceed the known diversity of these groups in Brazil, possibly because the fauna of that area has been studied more intensively over a much longer period of time. The number of species of these taxa may certainly experience a high increase with more intense studies in great depths and along the water column. A marked increase in the number of species of these taxa from Brazil may certainly be expected following more intensive studies of the fauna at great depths and along the water column.

Conversely, for the so-called hydroids (Anthoathecata + Leptothecata), the Antarctic continent (coastline of $17968 \mathrm{~km}$ ) has only ca. 130 species (ca. 30 genera; Peña Cantero, pers. comm.) and its fauna is considered depauperate due to habitat conditions, isolation, and high endemism.

The coast around Bermuda a small subtropical island with a depauperate West Indian fauna, yielded 118 species of hydroids ( ca. 60 genera; Calder, 2000). Moreover, a comparison with equivalent regions having better-known faunas (e.g., Mediterranean Sea, mostly European records, 296 species, ca. 150 genera, Boero \& Bouillon, 1993, Boero et al., 1997; southern Africa, 251 species, ca. 90 genera, Millard, $1975,1978)$ suggests that the fauna of Brazil is still inadequately known. Such data indicate that the hydroids (Leptothecata and Anthoathecata) of Brazil are more poorly known than the planktonic groups (Narcomedusae, Trachymedusae, and Siphonophorae).

As already stated, Brazil has an extensive and highly diverse territory and coastline. Opportunities for scientific study vary from one region to another along the coast as a result of differences in funding, availability of scientific personnel, equipment, etc. Wealthier states such as São Paulo and Rio de Janeiro have more resources to carry out extensive research programs. Moreover, the diverse physiographical conditions of the Brazilian coastline demand different requirements regarding accessibility of the environments and establishment of research infrastructure. The northern coast, highly influenced by Amazon River outflow, has extensive mangrove ecosystems which are still unstudied. The northeast coast is characterized by reef formations (only a small part of them being true coral reefs), along with high temperatures and intense incidence of light in shallow waters. Southeastern Brazil has many accessible coastal habitats, characterized by rocky shores bordering estuaries with mangrove and sandy beaches. Most of the coast of southern Brazil is sandy beach. These differences emphasize that knowledge of the fauna is uneven geographically, and determined in part by historical trends such as the greater emphasis of work on hydrozoans and scyphozoans in the state of São Paulo.

The uneven knowledge is clearly seen when the number of species recorded for each state and region is compared (Table 2). For instance, São Paulo has more catalogued hydrozoans than all other states have catalogued cnidarians in general (Rio de Janeiro excepted). The proximity to key states of Brazil (São Paulo and Rio de Janeiro) has a synergistic action and the neighbor areas are also consequently better known (e.g., Espírito Santo and Bahia).

However, as far as the state/region is distant from the axis São Paulo-Rio de Janeiro (and its area of influence and collections - basically from São Paulo to Bahia), less is known about the fauna (with few exceptions like Pernambuco). For instance, except for generalizations such as those made for siphonophores, it seems unlikely that there are no Cubozoa or Scyphozoa in Atol das Rocas, Fernando de Noronha, and Trindade; nor Hydrozoa in Amapá; or only a few (one to 12 species) of hydrozoans in Alagoas, Ceará, Piauí, Maranhão, Pará; Paraíba, Rio Grande do Norte, Sergipe, Atol das Rocas, and Trindade. Even in southern states, like Paraná and Santa Catarina, biodiversity is certainly underestimated ( 20 and 18 species of Hydrozoa, respectively; siphonophores excluded). Therefore, although we note progress in some areas, the total knowledge is unevenly distributed, and much more stimulated by individual actions than by wide research programs.

Finally, another constraint in knowledge of Brazilian cnidarians is related to the bathymetry of the samples. The majority of the samples and, consequently, the records al- 
ready done, are from shallow waters. This seriously constrains the possibilities for an adequate idea about the faunistic components of the Brazilian shore. It is known that many different species do exist at different depths in the same area (e.g., the shallow and deep fauna of Bermuda studied by Calder, 1988, 1991, 1996, 1997, 1998; Marques \& Calder, 2000). In Brazil this fauna is almost completely underestimated.

Studies on Brazilian medusozoans began in the $19^{\text {th }}$ century. The first paper, by Eschscholtz (1829), described Chrysaora lactea. The next was by Lesson (1830), who recorded both C. lactea and Catostylus cruciatus (Lesson, 1830). These authors were followed by Müller (1859a, 1859b, 1861a, 1861b, 1865, 1883), who provided a series of accounts describing two species of Cubozoa, four of Hydrozoa, and one of Scyphozoa for Santa Catarina state where the naturalist lived. The first major oceanographic expedition to visit Brazilian waters, that of H.M.S. Challenger, occurred toward the end of the century. The first accounts of polypoid phases from Brazil, based on 10 species of leptothecates, were from Challenger collections (Allman, 1883, 1888). The 20th century began with 11 new records of species of leptothecates (Jäderholm, 1903; Nutting, 1904; and Ritchie, 1909). By that time, and up to the 1990s, only sporadic records appeared of cubozoans and scyphozoans (maximum of 2, generally 01 records per decade). Meanwhile, a rapid increase occurred during the mid-20th century in numbers of species of hydrozoans reported from the country. This commenced in the late 1940s (one new record each of Anthoathecata and Limnomedusae; 27 of Leptothecata); reached an apogee during the 1950s (17 new records of Anthoathecata; 15 of Leptothecata; eight of Narcomedusae; and six of Trachymedusae), declined again during the 1960s (seven new records of Anthoathecata; five of Leptothecata; and one of Trachymedusae). This burst of knowledge of hydrozoan systematics was due to the studies of Dr. Marta Vannucci (Vannucci Mendes, 1946, 1948; Vannucci, 1949; 1950, 1951a, 1951b; 1954; 1956; 1957a; 1957b; 1960; 1963; Vannucci \& Ribeiro, 1955; Vannucci \& Rees, 1961; Vannucci $\&$ Moreira, 1966). Vannucci was followed during the ' 1970 s by her student, Maria da Gloria B.S. Moreira (Moreira \& Yamashita, 1972; Moreira, 1973, 1975; Moreira et al., 1978, 1979). Her work and important contributions by Goy (1979) and Navas-Pereira (1980) comprised the primary contributions to Brazilian hydrozoan studies of the decade. The first records of siphonophores were also made in the 1970s when Alvariño (1971) reported 49 species. Later, Alvariño (1981) provided eight new records and Pugh (1999) contributed 26 new records. During the 1980s, Navas-Pereira (1981, 1984a, 1984b) commenced her studies on medusae, especially along the coast of Rio Grande do Sul; and Ramirez \& Zamponi (1981) published their compilation study on the subject. After a hiatus of more than 20 years, polyp studies were resumed by Moreira (Moreira et al., 1978, 1979), Maÿal
(Maÿal, 1983) and Silveira and Migotto (Silveira \& Migotto 1984, Silveira et al., 1988; Migotto \& Silveira, 1987). Polyps continued to be the subject of research of the latter authors, and they were followed by Marques and other students. As a result, at the end of 1990's the number of recorded species for hydroids had increased significantly (33 new records for Anthoathecata and 30 for Leptothecata; cf. e.g., Bouillon \& Grohmann, 1990, 1994; Silveira \& Migotto, 1991, 1992; Pires et al., 1992; Marques, 1993, 1995; Migotto, 1996, 1998; Grohmann et al., 1997; Nogueira et. al., 1997; Calder \& Maÿal, 1998; Kelmo \& de Santa-Isabel, 1998; Migotto \& Calder, 1998; Migotto \& Vervoort, 1998; Migotto \& Marques, 1999a, b; Migotto \& Andrade, 2000; Lindner \& Migotto, 2001, 2002). Subsequent works have added new records for Brazilian waters (e.g., Marques, 2001; Migotto et al., 2001) including plankton studies (Tronolone, 2001). Many new records of scyphozoans and especially Coronatae have been added since the 1990s, with studies by Silveira \& Morandini (1996, 1997, 1998a, 1998b), Grohmann et al., 1999, Silveira \& Cornelius (2000), Morandini \& Silveira (2001a, 2001b), Jarms et al. (2002), and Tronolone et al. (2002).

An account of new species records of Hydrozoa and Scyphozoa is summarized in Table 3 and the data of Table 3 , figures 2 and 3. For Hydrozoa (figure 2), it is interesting to notice that Narcomedusae, Trachymedusae, and Limnomedusae have convergent curves, probably because of the lack of studies on these groups in recent decades; Siphonophorae had pulses of growth and stagnation. Anthoathecata and Leptothecata, on the contrary, have ascending curves, suggesting many records will occur with intensification of studies. For the Scyphozoa, the curves gradually ascend, except that of Coronatae, with a rapid rise in the last decade.

\section{General remarks and guidelines for the future}

At the most basic biological level of knowledge, the alpha-taxonomy of species, the medusozoan biota of Brazil is still poorly known in relation to many of the other regions of the globe. Even in the most studied parts of the country, such as the states of the Southeast region, faunal knowledge is inadequate. There is a need for 1) more intensive work on several groups (e.g., Anthoathecata, Leptothecata, Coronatae), 2) more funds for sampling and museum collections, 3) decentralization of collections and studies.

The most critical points highlighted by our results are: 1) poor general knowledge of all medusozoans, benthic and planktonic alike, of the North and Northeast (from Sergipe to Amapá); 2) insufficient knowledge of both benthic and planktonic medusozoans of the South region; 3) insufficient knowledge of planktonic forms across the entire Brazilian coast; 4) complete lack of knowledge of the whole medusozoan benthic and mesopelagic faunae of deeper 
continental shelf, bathyal, and abyssal waters.

Solutions for these problems demand organization and financial support. We believe that training of systematists should be a priority policy, not only those studying cnidarians but also many other animal groups ( $c f . e . g$, Migotto \& Marques, in press). Comprehensive monographs on specific groups should be undertaken because they bring thorough and qualified results over a relatively short period. An improvement in the quality and number of Brazilian collections is of utmost importance for continuity of studies, preservation of data, and availability of specimens for the future. The present number of natural history museums in Brazil is small, and the conservation of their collections is usually neglected due to scarce personnel and low budgets.

In our view Brazil is one hundred years behind Europe in knowledge of Medusozoa, and more so for some other groups. All proposals herein are indispensable to reach even a most basic informational level. A better understanding of the taxonomy of our marine biota will facilitate other research, such as that on pharmacology, ecology, and phylogeny. We do not suggest postponing these studies, but call attention in particular to our lack of most fundamental knowledge, that of basic organismal biodiversity.

\section{Acknowledgements}

The authors thank Fábio L. da Silveira (IBUSP) and two anonymous referees for suggestions to the manuscript. The study received financial support from the Fundação de Amparo à Pesquisa do Estado de São Paulo (FAPESP 1996/ 1415-2, 1996/1416-9, 1996/10544-0, 1997/03325-3, 1997/081370, 1998/11072-0, 1998/07090-3, 1999/05374-7, 1999/12433-0, 2001/02626-7, 2003/02432-3). A.C. Marques and A.E. Migotto have financial support from CNPq (300271/2001-8 and 300194/1994-3).

\section{References}

ALLMAN, G.J. 1883. Report on the Hydroida dredged by H.M.S. Challenger during the years 1873-76. Rep. Sci. Res. Challenger Exp. (Zool. Ser.) 7(20): 1-55.

ALLMAN, G.J. 1888. Report on the Hydroida dredged by H.M.S. Challenger during the years 1873-76. Part II. The Tubularinae, Corymorphinae, Campanularinae, Sertularinae and Thalamophora. Rep. Sci. Res. Challenger Exp. (Zool. Ser.) 23: 1-90.

ALVARIÑO, A. 1971. Siphonophores of the Pacific with a review of the world distribution. Bull. Scripps Inst. Oceanogr. 16: 1-432.
ALVARIÑO, A. 1981. Siphonophorae. In Atlas del zooplancton del Atlántico sudoccidental y metodos de trabajo con el zooplancton marino (D. Boltovskoy, ed.). INIDEP, Mar del Plata, p. 383-441.

BOERO, F. \& BOUILLON, J. 1993. Zoogeography and life cycle patterns of Mediterranean hydromedusae (Cnidaria). Biol. J. Linn. Soc. 48(3): 239-266.

BOERO, F., GRAVILI, C., DENITTO, M., MIGLIETTA, M.P. \& BOUILLON, J. 1997. The rediscovery of Codonorchis octaedrus (Hydroidomedusae, Anthomedusae, Pandeidae), with an update of the Mediterranean hydroidomedusan biodiversity. It. J. Zool. 64: 359-365.

BOLTOVSKOY, D., GIBBONS, M.J., HUTCHINGS, L. \& BINET, D. 1999. General biological features of the South Atlantic. 1-42. In: South Atlantic Zooplankton (D. Boltovskoy, ed.). Backhuys Publishers, Leiden, Vol. 1, p. $1-42$.

BOUILLON, J. 1994. Embranchement des cnidaires (Cnidaria). In Traité de Zoologie, Tome III, Fascicule 2. Cnidaires et Ctenaires (J. Bouillon, C. Carré, D. Carré, A. Franc, J. Goy, M-L. Hernandez-Nicaise, Y. Tiffon, D. van de Vyver \& M. Wade, eds). Masson, Paris, p. 1-28.

BOUILLON, J. \& GROHMANN, P.A. 1990. Pinushydra chiquitita gen. et sp. nov. (Cnidaria, Hydrozoa). Cah. Biol. Mar. 31: 291-305.

BOUILLON, J. \& GROHMANN, P.A. 1994. A new interstitial stolonal hydroid: Nannocoryne gen. nov. mammylia sp. nov. (Hydroidomedusae, Anthomedusae, Corynidae). Cah. Biol. Mar. 35: 431-439.

CALDER, D.R. 1988. Shallow-water hydroids of Bermuda: The Athecatae. Life Sci. Contri. R. Ontario Mus. 148: 1107.

CALDER, D.R. 1991. Shallow-water hydroids of Bermuda: The Thecatae, exclusive of Plumularioidea. Life Sci. Contri. R. Ontario Mus. 154: 1-140.

CALDER, D.R. 1996. Hydroids (Cnidaria: Hydrozoa) recorded from depths exceeding $3000 \mathrm{~m}$ in the abyssal western North Atlantic. Can. J. Zool. 74(9): 1721-1726.

CALDER, D.R. 1997. Shallow-water hydroids of Bermuda: superfamily Plumularioidea Life Sci. Contri. R. Ontario Mus. 161: 1-85.

CALDER, D.R. 1998. Hydroid diversity and species composition along a gradient from shallow waters to deep sea around Bermuda. Deep-Sea Res. I 45: 1843-1860.

CALDER, D.R. 2000. Assemblages of hydroids (Cnidaria) from three seamounts near Bermuda in the western North Atlantic. Deep-Sea Res. I 47: 1125-1139.

CALDER, D.R. \& MAŸAL, E.M. 1998. Dry season distribution of hydroids in a small tropical estuary, Pernambuco, Brazil. Zool. Verh. Leiden 323: 69-78. 
ESCHSCHOLTZ, F. 1829. System der Acalephen. Eine ausführliche Beschreibung aller medusenartigen Strahltiere. Ferdinand Dümmler, Berlin.

FREITAS, J.C., SCHIOZER, W.A. \& MALPEZZI, E.L.A. 1995. A case of envenoming by Portuguese man-of-war from the Brazilian coast. Toxicon 33(7): 859-861.

GOY, J. 1979. Campagne de la Calypso au large des côtes atlantiques de l'Amérique du Sud (1961-1962) - 35. Méduses. Resul. scient. camp.Calypso 11: 263-296.

GROHMANN, P.A., SOUZA, M.M. \& NOGUEIRA, C.C. 1997. Hydroids from the vicinity of a large industrial area in Vitória, Espírito Santo, Brazil. Proceedings of the VI International Conference on Coelenterate Biology, Leiden, The Netherlands: 227-232.

GROHMANN, P.A., M.P. MAGALHÃES \& Y.M. HIRANO 1999. First record of the order Stauromedusae (Cnidaria, Scyphozoa) from the tropical Soutwestern Atlantic, with a review of the distribution of Stauromedusae in the southern hemisphere. Species Diversity 4: 381-388.

HADDAD JR., V., SILVEIRA, F.L., CARDOSO, J.L.C. \& MORANDINI, A.C. 2002. A report of 49 cases of cnidarian envenoming from southeastern Brazilian coastal waters. Toxicon 40(10): 1445-1450.

JÄDERHOLM, E. 1903. Aussereuropäische hydroiden in Schwedischen Reichsmuseum. Ark. Zool. 1: 259-312.

JARMS, G., MORANDINI, A.C. \& SILVEIRA, F.L. 2002. Polyps of the families Atorellidae and Nausithoidae (Scyphozoa: Coronatae) new to the Brazilian fauna. Biota Neotropica 2(1).

KELMO, F. \& DE SANTA-ISABEL, L.M. 1998. The athecatae hydroids (Cnidaria, Hydrozoa) from Northern Bahía, Brazil. Rev. Biol. Trop. 46 (supl.5): 61-72.

KIRKPATRICK, P.A. \& PUGH, P.R. 1984. Siphonophores and Vellelids. Synopsis of the British Fauna (New Series), n. 29. Linnean Society of London, London.

LESSON, R.P. 1830. Voyage autour du monde, exécuté par ordre du Roi sur la corvette La Coquille, pendant les anées 1822-1825. Zoologie t.2(2): 1-135.

LEWINSOHN, T.M. \& PRADO, P.I. 2002. Biodiversidade Brasileira. Síntese do estado atual do conhecimento. Editora Contexto, São Paulo.

LINDNER, A. \& MIGOTTO, A.E. 2001. Merotrichous isorhiza, a new nematocyst in the Campanulariidae (Cnidaria; Hydrozoa), and its relevance for the classification of cnidae. Proc. biol. Soc. Wash. 114(4): 825-832.

LINDNER, A. \& MIGOTTO, A.E. 2002. The life cycle of Clytia linearis and Clytia noliformis: metagenic campanulariids (Cnidaria Hydrozoa) with contrasting polyp and medusa stages. J. Mar. Biol. Ass. U.K. 82: 541-553.
MACILWAIN, C. 1999. Collapse of real sharpens Brazil's contrasts. Nature 398(6726): A16-A18 Suppl.

MARQUES, A.C. 1993. Sistemática dos Eudendriidae L. Agassiz, 1862 (Cnidaria, Hydrozoa) do litoral Paulista. São Paulo. MSc. Dissertation, Universidade de São Paulo, São Paulo.

MARQUES, A.C. 1995. Eudendrium pocaruquarum n. sp. (Hydrozoa, Eudendriidae) from the southeastern coast of Brazil, with remarks on taxonomic approaches to the family Eudendriidae. Contr. Zool. 65(1): 35-40.

MARQUES, A.C. 2001. O gênero Eudendrium (Cnidaria, Hydrozoa, Anthoathecata) no Brasil. Pap. Av. Zool. 41(22): 329-405.

MARQUES, A.C. \& CALDER, D.R. 2000. Eudendrium bathyalis, a new species of hydroid (Hydrozoa: Anthomedusae: Eudendriidae) from Bermuda. Proc. Biol. Soc. Wash. 113(1): 124-128.

MARQUES, A.C. \& COLLINS, A.G. 2004. Cladistic analysis of Medusozoa and cnidarian evolution. Inv. Biol. (in press).

MARQUES, A.C., HADDAD, V. \& MIGOTTO, A.E. 2002. Envenomation by a benthic Hydrozoa (Cnidaria): the case of Nemalecium lighti (Haleciidae). Toxicon 40: 213215.

MAŸAL, E.M. 1983. Distribuição de hidróides (Hydrozoa, Thecata) na costa do estado de Pernambuco, Brasil. Bolm. Zool. Univ. S. Paulo 8: 1-13.

MIANZAN, H.W. \& CORNELIUS, P.F.S. 1999. Cubomedusae and Scyphomedusae. In South Atlantic Zooplankton (D. Boltovskoy ed.). Backhuys Publishers, Leiden, Vol. 1, p.513-559.

MIGOTTO, A.E. 1993. Hidróides (Hydrozoa, Cnidaria) marinhos bentônicos da região costeira de São Sebastião, SP. PhD Dissertation. Universidade de São Paulo, São Paulo.

MigOTTO, A.E. 1996. Benthic shallow-water hydroids (Cnidaria, Hydrozoa) of the coast of São Sebastião, Brazil, including a checklist of Brazilian hydroids. Zool. Verh. 306: $1-125$.

MIGOTTO, A.E. 1998. The life cycle of Sertularia marginata Kirchenpauer, 1864 (Cnidaria: Hydrozoa): a medusoidproducing sertulariid. J. nat. Hist. 32: 1-12.

MIGOTTO, A.E. \& ANDRADE, L.P. 2000. The life cycle of Hebella furax (Cnidaria: Hydrozoa): a link between a lafoeid hydroid and a laodiceidae medusae. J. nat. Hist. 34: 1871-1888.

MIGOTTO, A.E. \& CALDER, D.R. 1998. Sertularia vervoorti (Hydrozoa: Sertulariidae), an undescribed species of hydroid from Brazil. Zool. Verh. 323:169-174. 
MIGOTTO, A.E. \& MARQUES, A.C. 1999a. Hydroid and medusa stages of the new species Ectopleura obypa (Cnidaria: Hydrozoa: Tubulariidae) from Brazil. Proc. biol. Soc. Wash. 112(2):303-312.

MIGOTTO, A.E. \& MARQUES, A.C. 1999b. Redescription of Dentitheca bidentata (Hydrozoa, Leptomedusae, Plumulariidae) with notes on its life cycle. J. nat. Hist 33: 949-960.

MIGOTTO, A.E. \& MARQUES, A.C. Avaliação do estado do conhecimento da diversidade de invertebrados marinhos no Brasil. In Ministério do Meio Ambiente Avaliação do estado do conhecimento da diversidade biológica do Brasil. MMA - GTB/CNPq. (in press)

MIGOTTO, A.E., MARQUES, A.C. \& FLYNN, M.N. 2001. Seasonal recruitment of hydroids (Cnidaria) on experimental panels in the São Sebastião Channel, Southeastern Brazil. Bull. Mar. Sci. 68: 287-298.

MIGOTTO, A.E., MARQUES, A.C., MORANDINI, A.C. \& SILVEIRA, F.L. 2002. Checklist of the Cnidaria Medusozoa of Brazil. Biota Neotropica 2(1).

MIGOTTO, A.E. \& SILVEIRA, F.L. 1987. Hidróides (Cnidaria, Hydrozoa) do litoral sudeste e sul do Brasil: Halocordylidae, Tubulariidae e Corymorphidae. Iheringia. sér. Zool. 66: 3-32.

MIGOTTO, A.E. \& VERVOORT, W. 1998. Redescription of Sertularia notabilis Fraser, 1947 (Sertulariidae, Hydrozoa). Zool. Med. 72: 89-100.

MILLARD, N.A.H. 1975. Monograph on the Hydroida of southern Africa. Ann. S. Afr. Mus. 68: 1-513.

MILLARD, N.A.H. 1978. The geographical distribution of southern African hydroids. Ann. S. Afr. Mus. 74(6): 159200.

MMA/SBF 2002. Biodiversidade Brasileira: avaliação de áreas e ações prioritárias para a conservação, utilização sustentável e repartição dos benefícios da biodiversidade nos biomas brasileiros. MMA, Brasília.

MORANDINI, A.C. \& MARQUES, A.C. 1997. "Morbakka" syndrome: first report of envenomation by Cubozoa (Cnidaria) in Brazil. In Boletim de Resumos Expandidos VII COLACMAR, Santos, v. 2, p.188-189.

MORANDINI, A.C. \& SILVEIRA, F.L. 2001a. Sexual reproduction of Nausithoe aurea (Scyphozoa, Coronatae). Gametogenesis, egg release, embryonic development, and gastrulation. Sci. Mar. 65(2): 139-149.

MORANDINI, A.C. \& SILVEIRA, F.L. 2001b. New observations and new record of Nausithoe aurea (Scyphozoa, Coronatae). Pap. Av. Zool. 41(27): 519-527.

MOREIRA, G.S. 1973. On the diurnal vertical migration of hydromedusae off Santos, Brazil. Publs Seto mar. biol. Lab. 20: 537-566.
MOREIRA, G.S. 1975. Sobre duas Leptomedusae do litoral do estado de São Paulo. Ciênc. Cult., S. Paulo 27(5): 556558.

MOREIRA, G.S., LEITE L.R. \& NIPPER, M.G. 1978. Notes on Dipurena reesi Vannucci 1956 (Hydrozoa, Corynidae) with a description of an unusual method of asexual reproduction. Bolm Fisiol. Anim., Univ. S Paulo 2: 159-164.

MOREIRA, G.S., NIPPER, M.G. \& LEITE, L.R. 1979. On Stylactis hooperi_Sigerfoos, 1899 (Hydrozoa, Hydractiniidae, a new addition to the fauna of southern Brazil. Proc. Internat. Symp. Mar. Biogeogr. Evolut. Southern Hemisph. New Zealand 2: 679-689.

MOREIRA, G. S. \& YAMASHITA, C. 1972. Aglauropsis kawari (Limnomedusae: Olindiasidae), a new species from the South Atlantic. Mar. Biol. 14(3): 271-274.

MÜLLER, F. 1859a. Polypen und Quallen von Santa Catharina. Die Formwandlungen der Liriope catharinensis n.sp. Archiv für Naturgeschichte 1: 310321. In Fritz Müller: Werke, Briefe und Leben. Erster Band: Gesammelte schriften sowiet sie bereits früher in druck erschienen sind (A Möller ed., 1915) Jena, vol. 1, p. 93100.

MÜLLER, F. 1859b. Zwei neue Quallen von Santa Catharina. Tamoya haplonema und quadrumana. Abhandlungen der Naturforschenden Gesellschaft in Halle 5: 1-12. In In Fritz Müller: Werke, Briefe und Leben. Erster Band: Gesammelte schriften sowiet sie bereits früher in druck erschienen sind (A Möller ed., 1915) Jena, vol. 1, p. 8592.

MÜLLER, F. 1861a. Polypen und Quallen von Santa Catharina. Olindias sambaquiensis n.sp. Archiv für Naturgeschichte 1:312-319. In Fritz Müller: Werke, Briefe und Leben. Erster Band: Gesammelte schriften sowiet sie bereits früher in druck erschienen sind (A Möller ed., 1915) Jena, vol. 1, p. 132-136.

MÜLLER, F. 1861b. Cunina Köllikeri n.sp. Beitrag zur Naturgeschichte der Aeginiden. Archiv für Naturgeschichte 1: 42-52. In Fritz Müller: Werke, Briefe und Leben. Erster Band: Gesammelte schriften sowiet sie bereits früher in druck erschienen sind (A Möller ed., 1915) Jena, vol. 1, p. 116-122.

MÜLlER, F. 1865. Über die Randbläschen der Hydroidquallen. Arch. mikr. Anat. 1: 143-147.

MÜLLER, F. 1883. Drymonema an der küste von Brasilien. Zool. Anz. 6: 220-222. In Fritz Müller: Werke, Briefe und Leben. Erster Band: Gesammelte schriften sowiet sie bereits früher in druck erschienen sind (A Möller ed., 1915) Jena, vol. 1, p. 999-1000.

NAVAS-PEREIRA, D. 1980. Hydromedusae of the Bay of Sepetiba (Rio de Janeiro, Brazil). Revta bras. Biol. 40(4):817-824. 
NAVAS-PEREIRA, D. 1981. Distribuição das hidromedusas (Cnidaria, Hydrozoa) na região da plataforma continental do Rio Grande do Sul. In Seminários de Biologia Marinha, São Paulo. Academia Brasileira de Ciências. p. 221-276

NAVAS-PEREIRA, D. 1984a. New record of budding in Zanclea costata (Anthomedusae, Zancleidae) Dusenia 14(3): 89-93.

NAVAS-PEREIRA, D. 1984b. On the morphological variability of Phialucium carolinae (Mayer, 1900) (Leptomedusae, Phialuciidae). Dusenia 14(2): 51-53.

NIELSEN, C. 2001. Animal Evolution: interrelationships of the living phyla. Oxford University Press, Oxford.

NUTTING, C.C. 1904. American hydroids. Part I. The Sertulariidae. Spec. Bull. U.S. natn. Mus. 4: 1-325.

PAGÈS, F. \& GILI, J.-M. 1992. Siphonophores (Cnidaria, Hydrozoa) of the Benguela Current (southeastern Atlantic). Sci. Mar. 56(Supl. 1): 65-112.

PAGÈS, F., GILI, J.-M. \& BOUILLON, J. 1992. Medusae (Hydrozoa, Scyphozoa, Cubozoa) of the Benguela Current (southeastern Atlantic). Sci. Mar. 56(Supl. 1): 1-64.

PALACIO, F.J. 1982. Revisión zoogeográfica marina del sur del Brasil. Bolm Inst. oceanogr., S Paulo 31(1): 69-92.

PIRES, D.O., CASTRO, C.B., MIGOTTO, A.E. \& MARQUES, A.C. 1992. Cnidários bentônicos do Arquipélago de Fernando de Noronha, Brasil. Bolm Mus. nac. Rio de Janeiro, Zool. 354: 1- 21.

PUGH, P.R. 1999. Siphonophorae. In South Atlantic Zooplankton (D. Boltovskoy, ed.). Backhuys Publishers, Leiden, Vol. 1, p. 467-511.

PURCELL, J.E., GRAHAM, W.M. \& DUMONT, H.J. (eds) 2001. Jellyfish blooms: ecological and societal importance. Hydrobiologia 451(Dev. Hydrob. 155): 1-333.

RAMÍREZ, F.C. \& ZAMPONI, M.O. 1981. Hydromedusae. In Atlas del zooplancton del Atlántico sudoccidental y metodos de trabajo con el zooplancton marino (D. Boltovskoy, ed). INIDEP, Mar del Plata, p 443-469.

RITCHIE, J. 1909. Supplementary report on the hydroids of the Scottish National Antartic Expedition. Trans. R. Soc. Edinb. 47: 65-101.

SCHUCHERT, P. 1998. How many hydrozoan species are there ? Zool. Verh. 323: 209-219.

SILVEIRA, F.L. \& CORNELIUS, P.F.S. 2000. Novas observações sobre medusas (Cnidaria, Scyphozoa, Rhizostomeae) no nordeste e sul do Brasil. Acta Biol. Leopold. 22(1): 9-18.

SILVEIRA, F.L. \& MIGOTTO, A.E. 1984. Serehyba sanctisebastiani n.gen., n.sp. (Hydrozoa, Tubulariidae), symbiont of a gorgonian octocoral from the southeast coast of Brazil. Bijdr. Dierk. 54(2):231-242
SILVEIRA, F.L. \& MIGOTTO, A.E. 1991. The variation of Halocordyle disticha (Cnidaria, Athecata) from the Brazilian coast: an environmental indicator species? Hydrobiologia 216/217: 437-442.

SILVEIRA, F.L. \& MIGOTTO, A.E. 1992. Rediscovery of Corymorpha januarii Steenstrup, 1854 (Hydrozoa, Corymorphidae) on the southeastern and southern coasts of Brazil. Steenstrupia 18(4): 81-89.

SILVEIRA, F.L., MIGOTTO, A.E. \& VIEITAS, C.F. 1988. Staurocladia Hartlaub, 1917 (Hydroida, Anthomedusae, Eleutheriidae) do infralitoral de Itaipava, ES, ocorrência nova. In Resumos do XV Congresso Brasileiro de Zoologia. SBZ, Curitiba, p 22.

SILVEIRA, F.L. \& MORANDINI, A.C. 1996. Stephanoscyphistoma corniformis (Komai, 1936) (Cnidaria, Scyphozoa, Coronatae) from the north coast of São Paulo, Brazil; redescription and the first record in the western South Atlantic. Semina 17(2):137-145.

SILVEIRA, F.L. \& MORANDINI, A.C. 1997. Nausithoe aurea n. sp. (Scyphozoa, Coronatae, Nausithoidae), a species with two pathways of reproduction after strobilation: sexual and asexual. Contr. Zool. 66(40):235-246.

SILVEIRA, F.L. \& MORANDINI, A.C. 1998a. Asexual reproduction in Linuche unguiculata (Swartz, 1788) (Scyphozoa: Coronatae) by planuloid formation through strobilation and segmentation. Proc. biol. Soc. Wash. 111(4):781-794.

SILVEIRA, F.L. \& MORANDINI, A.C. 1998b. New observations on dormancy mechanisms in Linuche unguiculata (Swartz, 1788) (Scyphozoa: Coronatae). Bol. Mus. Nac., N.S., Zool. 393:1-7.

TRONOLONE, V.B. 2001. Hidromedusas (Cnidaria, Hydrozoa) do canal de São Sebastião, SP. MSc Dissertation, Universidade de São Paulo, São Paulo.

TRONOLONE, V.B., MORANDINI, A.C.\& MIGOTTO, A.E. 2002. On the occurrence of scyphozoan ephyrae (Cnidaria, Scyphozoa, Semaeostomeae and Rhizostomeae) in the southeastern Brazilian coast. Biota Neotropica 2(2)

UNEP 1991. Jellyfish blooms in the Mediterranean. Proceedings of the II Workshop on Jellyfish in the Mediterranean Sea. MAP Tech. Rep. Series 47: 1-320.

VANNUCCI-MENDES, M. 1946. Hydroida Thecaphora do Brasil. Arq. Zool. Estado São Paulo 4: 535-538.

VANNUCCI-MENDES, M. 1948. On Vallentinia gabriellae, n. sp. (Limnomedusae). Bolm Fac. Filos. Ciênc. Univ. S Paulo, Zool. 13: 73-91.

VANNUCCI, M. 1949. Hydrozoa do Brasil. Bolm Fac. Filos. Ciênc. Univ. S Paulo 99(14): 219-266. 
VANNUCCI, M. 1950. Resultados científicos do Cruzeiro do "Baependi" e do "Vega" a Ilha da Trindade. Hydrozoa. Bolm Inst. oceanogr., S Paulo 1(1): 81-96.

VANNUCCI, M. 1951a. Hydrozoa e Scyphozoa existentes no Instituto Paulista de Oceanografia. I. Bolm Inst. oceanogr., S Paulo 2(1): 67-98.

VANNUCCI, M. 1951b. Distribuição dos Hydrozoa até agora conhecidos nas costas do Brasil. Bolm Inst. oceanogr., S Paulo 2(1): 105-124.

VANNUCCI, M. 1954. Hydrozoa e Scyphozoa existentes no Instituto Oceanográfico. II. Bolm Inst. oceanogr., S Paulo 5(1-2): 95-149.

VANNUCCI, M. 1956. Biological notes and description of a new species of Dipurena (Hydrozoa, Corynidae). Proc. Zool. Soc. Lond. 127:479-487.

VANNUCCI, M. 1957a. On Brazilian hydromedusae and their distribution in relation to different water masses. Bolm Inst. oceanogr., S Paulo 8(1-2): 23-109.

VANNUCCI, M. 1957b. Distribuição de Scyphozoa nas costas do Brasil. An. acad. bras. Ciênc. 29(4): 593-598.

VANNUCCI, M. 1960. On the young stage of Eucheilota duodecimalis (Leptomedusae). An. acad. bras. Ciênc. 32(3/4): 395-397.

VANNUCCI, M. 1963. On the ecology of Brazilian Medusae at 25o lat. S. Bolm Inst. oceanogr., S Paulo 13(1):143-184.

VANNUCCI, M. \& MOREIRA, G.S. 1966. New species and new record of Anthomedusae from southern Brazil. Bolm. Inst. oceanogr., S Paulo 15: 85-90.

VANNUCCI, M. \& REES, W.J. 1961. A revision of the genus Bougainvillia (Anthomedusae). Bolm Inst. oceanogr., S Paulo 11(2): 57-100.

VANNUCCI, M. \& RIBEIRO, L.C. 1955. O ciclo reprodutivo de Clytia cylindrica L. Agass., 1862 (Hydrozoa: Campanulariidae). Dusenia 6(3/4): 69-80.

VILAÇA, R. 2002. Recifes Biológicos. In Biologia Marinha (R.C. Pereira \& A. Soares-Gomes, eds). Interciência, Rio de Janeiro. p. 229-248.
Title: Synopsis of knowledge on Cnidaria Medusozoa from Brazil

Authors: Antonio C. Marques, André C. Morandini Alvaro E. Migotto

Biota Neotropica, Vol. 3 ( number 2): 2003

http://www.biotaneotropica.org.br/v $3 \mathrm{n} 2 / \mathrm{pt} /$ abstract?inventory+BN01203022003

Date Received : 07/14/2003

Accepted :08/26/2003

ISSN 1676-0611 